ISSN 0258-7122 (Print), 2408-8293 (Online)

Bangladesh J. Agril. Res. 41(4): 657-665, December 2016

\title{
IDENTIFICATION OF OKRA SHOOT AND FRUIT BORER INFESTING OKRA AND THEIR DISTRIBUTION IN BANGLADESH
}

\author{
M. A. MAZED ${ }^{1}$, M. Z. ALAM ${ }^{2}$, M. R. U. MIAH ${ }^{3}$ \\ M. S. HOSSAIN ${ }^{4}$ AND M. I. H. MIAN ${ }^{5}$
}

\begin{abstract}
A survey was conducted during July 2009 to October 2010 to know the occurrence of okra shoot and fruit borer species that infest okra in Bangladesh. Infested okra fruits were collected from eleven selected locations representing 11 Agro-ecological Zones of Bangladesh and reared in the laboratory. A total of 423 adult individuals consisting of 188 male and 235 female moths emerged from the infested fruits. The male and female ratio was 1.00:1.25. The morphological characteristics of adult moths were recorded. Head and thorax of adults are ochreous white; forewings are pale white with a wedge shaped horizontal green patch in the middle and hind wings are silvery creamy white in color. The males are smaller than the females in size and the females are $\mathrm{V}$ shaped at the end of the anal part but the males have thick hairs at the end of the anal part. Pupae are chocolate brown, bluntly rounded and enclosed in grey colored inverted boat shaped cocoon formed in the fruit or in the sand. Full grown caterpillars measured $1.64 \mathrm{~cm}$ in length and their color is brownish with white streaks dorsally and pale yellow ventrally, without finger tipped process. The recorded morphological characteristics ware compared with standard key and the insects were identified as Earias vittella belonging to the family Noctuidae.
\end{abstract}

Keywords: Identification, Distribution, Earias vittella, Okra, Okra shoot and fruit borer.

\section{Introduction}

Okra shoot and fruit borer (OSFB) is considered to be the major insect pest of the crop, which interferes with its economic production in almost all okra growing countries. Srinivasan and Gowder (1959) reported that the pest may cause $40-50 \%$ damage of fruit in some areas of south-east Asian countries. Krishnaiah (1980) observed that the insects attack fruits and cause 35\% damage in harvestable fruit in India. In Bangladesh, OSFB is noted as the major insect pest of okra causing tremendous yield losses (Alam, 1969; Ali, 1992).

A total of 130 species of Earias were so far identified worldwide and found to attack many crops particularly under Malvaceae family (Ali and Karim, 1990; Gautam and Goswami, 2004). Ambekar et al. (2000) reported that two species of

${ }^{1}$ Department Agricultural Extension, Dhaka, ${ }^{2-4}$ Department of Entomology, Bangabandhu Sheikh Mujibur Rahman Agricultural University (BSMRAU), Gazipur, ${ }^{5}$ Department of Plant Pathology, BSMRAU, Gazipur, Bangladesh. 
Earias namely E. vittella and E. insulana attack the shoot and fruit of okra in India. Earias vettelle has been identified as the major pest of okra also in other countries (Gapud, 1993). Alam (1962) reported that 3 species of Earias, namely E. cupreoviridis W, E. fabia $\mathrm{S}$ and E. insulana (B) occur in Bangladesh. They attack both okra and cotton fruits and other Malvaceous plants. The name of $E$. fabia has been changed to $E$. vittella.

Atwal (1976) reported that E. vitteila is widely distributed in North Africa, India, Pakistan and other countries and is a serious pest of okra and cotton. Satpute et al. (2002) studied different hosts of E. vittella and found that okra was the most preferred host for the development of the pest, followed by cotton, artificial diet and mesta (Hibiscus sp.).

After 1962, no comprehensive work has been undertaken in Bangladesh to identify different species of OSFB attacking okra cultivated throughout the country. As the country is surrounded by India, there is possibility of invasion of new species of this pest into Bangladesh. For the proper management of any pest, accurate identification of species is essential. Therefore, investigation was conducted to determine the present status of OSFB species in Bangladesh.

\section{Materials and Method}

The present survey was conducted at 11 selected locations in 11 regions under 11 agro ecological zones of Bangladesh, where okra is grown extensively (Table 1). Shoot and fruit borer infested fruits of okra were collected from the selected locations during the cropping season of July 2009 - October 2010. Specimens were collected from 5 fields belonging to 5 farmers at each location. A total of 20 infested okra fruit in a field of a farmer, so100 specimens per location was picked up and placed inside plastic pots $(35 \mathrm{~cm} \times 30 \mathrm{~cm})$ containing sand at the bottom with a filter paper on it and the mouth of the pot was covered with mosquito net using rubber band. The pots with specimens were carried to the laboratory in net bag to ensure proper aeration. Table 1 indicates the date of collection of the infested specimens from 11 different locations. Rearing boxes were kept ready at entomology laboratory, Bangabandhu Sheikh Mujibur Rahman Agricultural University, Gazipur before the specimen brought back.

\section{Rearing of okra shoot and fruit borer}

Infested okra fruits collected from different locations were placed separately in netted rearing cage $(30 \mathrm{~cm} \times 30 \mathrm{~cm})$ containing sand at the bottom and placed on laboratory desk under room temperature (Figure 1). Full grown larvae moved out of the infested fruit and some of them pupated on the fruit and some pupated on the sand placed at bottom. Adult emerged from full grown pupae after 7 to 12 days of pupation. Emerged adults were placed separately in a killing jar and their number was counted. Adult moths were then pinned, stretched and preserved for identification. 


\section{Identification of okra shoot and fruit borer moths}

Specimens were primarily identified with the help of taxonomic keys described by Alam (1969) and Butani and Jotwani (1984). For this purpose specific characters of each specimen were studied thoroughly and checked with the characters of the keys (Alam, 1969; Butani and Jotwani, 1984). All the characters were studied under binocular microscope. Any morphological variation of the adults proved them different species. Larval characteristics were also considered to confirm identification.

Table 1. Infested okra fruits collected from 11 selected locations along with the dates of collection and rearing

\begin{tabular}{l|c|c}
\hline Selected locations & Date of sample collection & Date of placing in rearing box \\
\hline Kaharole, Dinajpur & 12 July 2009 & 14 July 2009 \\
Panchbibi, Joypurhat & 12 July 2009 & 14 July 2009 \\
Gazipur Sadar & 27 July 2009 & 14 July 2009 \\
Kurigram sadar & 17 July 2009 & 18 July 2009 \\
Mirersorai, Chittagong & 8 August 2009 & 9 August 2009 \\
Ashashuni, Shatkhira & 13 August 2010 & 14 August 2010 \\
Porshuram, Feni & 19 August 2010 & 20 August 2010 \\
Ishardi, Pabna & 25August 2010 & 26 August 2010 \\
Gangnee, Meherpur & 31 August 2010 & 1September 2010 \\
Kustia Sadar & 27 September 2010 & 28 September 2010 \\
Jhikargacha, Jessore & 10 October 2010 & 11 October 2010 \\
\hline
\end{tabular}
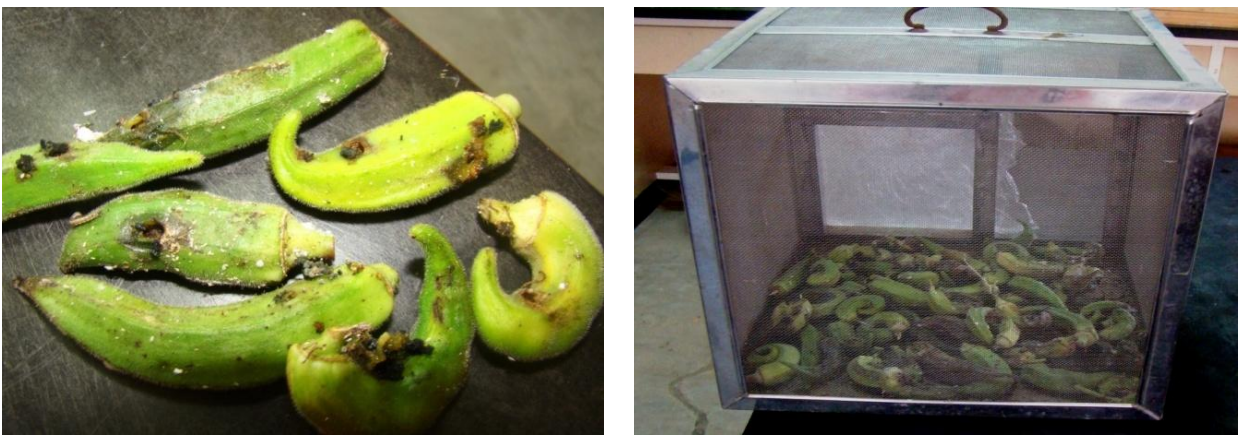

Fig. 1. Rearing of okra shoot and fruit borer in rearing box.

\section{Results and Discussion}

A total of 423 individuals representing 188 males and 235 females emerged from the collected specimens of 11 locations. Taxonomic study indicated that there was only 1 species (vittella) belonging to one genus, Earias under the family Noctuidae (Table 2). Its identifying characteristics, description, number and percentage of total adult individuals emerged from the reared okra fruits and their distribution are shown in Table 2. 


\section{Identifying characteristics of Earias}

The adult characteristics described by Alam (1969) and Butani and Jotwani (1984) were compared with each of the emerged adults of eleven locations. Results indicated that the adult morphological characteristics were completely comparable to those of Earias vittella only. No morphological variations were observed among the emerged adults of both male and female. Therefore, the emerged adults of eleven locations of Bangladesh were belonging to only one genus (Earias) under a family (Noctuidae) but the previous reports indicated that the okra fruit in particular are infested by three species of Earias. Alam (1962) reported that 3 species of Earias, namely E. cupreoviridis W., E. fabia S. and E. insulana (B.) bored into both okra and cotton fruit. He observed that these species attacked other malvaceous plant in Dhaka. Alam (1969) reported that $E$. fabia S. later renamed as E. Vittella (F.) which appeared as the major borer pest of okra in Bangladesh. In the present study, only E. vittella was found as the major pest of okra in all the locations.

The result of the present investigation contradicts with the findings of Alam (1962). This might be due to the fact that almost all locations were extensively cultivated with okra. There was no cotton cultivation in the selected spots of the survey. Earias cupreoviridis and E. insulana are the major borer pest of cotton but they choose okra as their alternate host where okra are cultivated closer to cotton plantation. The adult (male and female) identification keys used by different author(s) and the present investigations are as follows:

1. Earias vittella $(\mathrm{F})$ adults are small measuring $1.25 \mathrm{~cm}$ across the forewing. The head and thorax of adults are ochreous white; forewings are pale white with a wedge shaped horizontal green patch in the middle (Fig. 1A) and hind wings are silvery creamy white in color (Fig. 1B). Similar Characterristics were described by Alam (1969) and Butani and Jotwani (1984). According to Atwal and Dhaliwal (1997), E. Vittella moth have narrow light longitudinal green band in the middle of forewing as found in the present study (Fig. 1A). The distinction between male and female is that the male is smaller than female in size and the female has V-shaped at the end of the anal part but the male has thick hair at the end of anal part found in this study (Not showed in figure as difficult to distinguish) is also described by another author (Anon., 2001).

2. Eggs are light bluish green having longitudinal ridges (Fig. 2C). These features were also observed by Alam (1969).

3. Full grown caterpillar measured $1.64 \mathrm{~cm}$ in length and its color is green, black and orange found in this study, was similarly observed by Alam (1969) (Fig. 2D). But Anon. (2001) reported that the larvae brownish with white streaks dorsally and pale yellow ventrally, without finger naped process. 
4. Pupation in rough, boat shaped grey cocoon formed on the fruit (plate 1E) or in the sand (Fig. 2F). But Butani and Jotwant (1984) reported that the pupae were chocolate brown, bluntly rounded and enclosed in grey colored inverted boat shaped cocoons. Present finding was comparable to those found by Alam (1962).

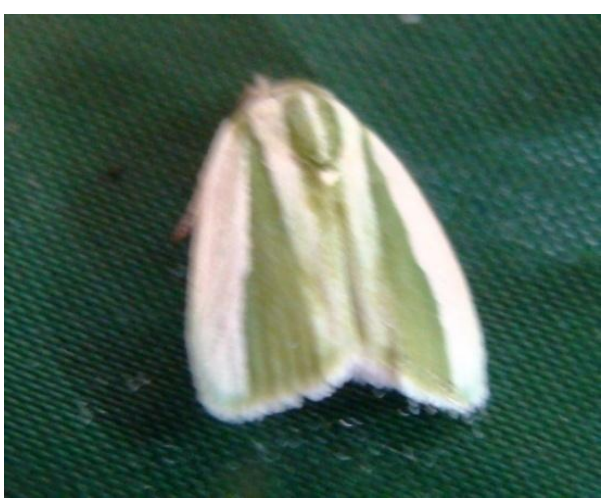

A. Fore wings of Earias vittella white with greenish band

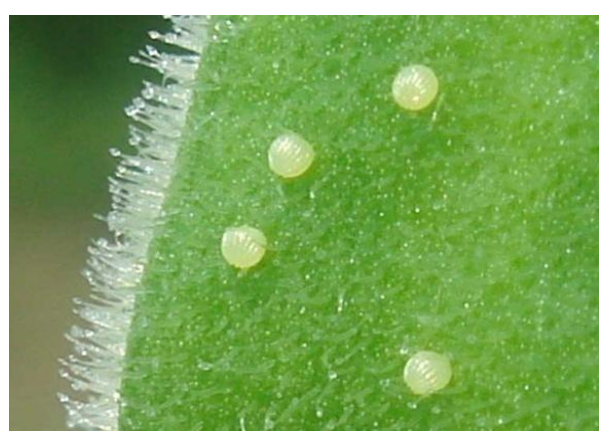

C. Eggs of Earias vittella

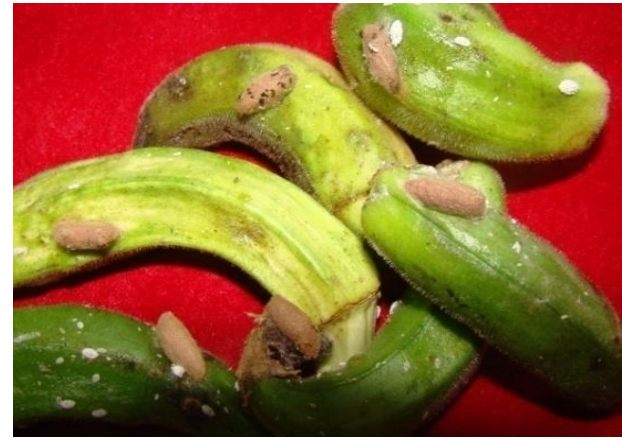

E. Cocoon formed on the fruit

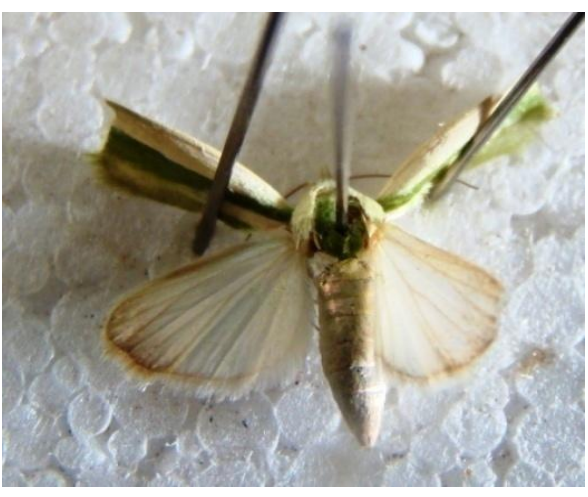

B. Hind wings of Earias vittella creamy white in color

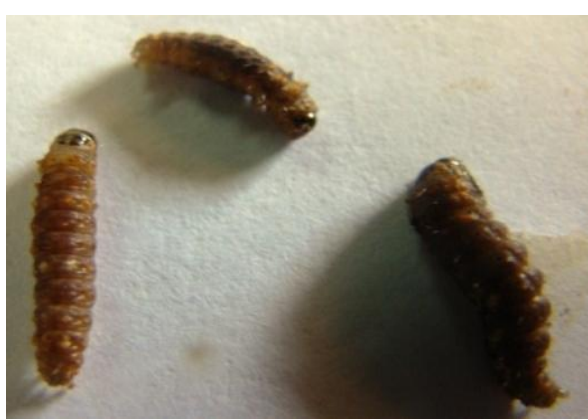

D. Larvae of Earias vittella

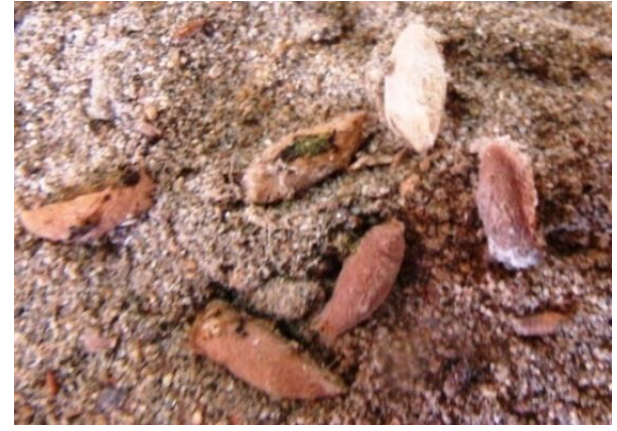

F. Cocoon formed on sand

Fig. 2. Morphological characteristics of larvae and adults of Earias vittella collected from infested fruits of okra. 


\section{Number of pupae and adults emerged}

The highest number of pupae (73) was produced from infested okra fruits collected from Kaharole, Dinajpur. The second highest number of pupae (70) was obtained from the samples collected from Ashashuni, Satkhira. On the other hand, the lowest number of pupae (56) was found from the collected samples of Jhikorgacha, Jessore. Almost similar number of pupae 68, 66 and 67 were recorded from the samples of Panchbibi, Jaypurhat, Gazipur Sadar and Porshuram, Feni, respectively. The number of pupae recorded from other locations ranged from 59-63 (Table 2). The highest number of adults (50) emerged from the pupae of Kaharole, Dinajpur followed by Panchbibi, Jaypurhat (44). The lowest number of adults (27) emerged from the pupae of Jhikorgacha, Jessore followed by Kustia Sadar, Kustia, (30) and Ishurdi, Pabna (32). The number of adults emerged from the pupae of Kurigram Sadar, Gangnee, Meherpur; Gazipur Sadar; Ashashuni, Satkhira; Mirersorai, Chittagong and Porshuram, Feni were 40, 40, 42, 42, 38 and 38, respectively (Table 2).

\section{Number of male and female moths emerged}

The number of male and female OSFB moths emerged from the pupae of different locations is presented in Table 2. The highest number (23) of male moths emerged from the pupae of Kaharole, Dinajpur and the second highest number (20) of male moths emerged from Ashasuni, Satkhira. Number of male moths of 18,18,18,19,16,16 emerged from the pupae of the samples collected from Panchbibi, Jaypurhat; Kurigram sadar; Mirersorai, Chittagong;, Gazipur Sadar, Gazipur; Porshuram, Feni and Gangnee, Meherpur, respectively. Male moth emergence were poor from the pupae of samples collected from Kustia Sadar (12), Jhikorgacha, Jessore (13), and Ishardi, Pabna (15).

The highest number (27) of female moths emerged from the pupae of the samples from Kaharole, Dinajpur and the second highest number (26) from the samples of Panchbibi, Jaypurhat followed by Meherpur (24) and Gazipur (23). Twenty two female moths emerged individually from the pupae of samples collected from Kustia, Shatkhira and Feni. The populations of female emerged in other locations ranged from 17-20. The lowest number (14) of female moth emerged from the pupae of samples collected from Jhikorgacha, Jessore. A total of 423 adult moths emerged from the collected hosts of 11 different locations. Of them 188 were males and 235 were females. The sex ratio of male: female was 1.00:1.25 (Table 2). 
Table 2. The number of OSFB emerged from infested okra samples from different okra growing areas of Bangladesh

\begin{tabular}{|c|c|c|c|c|c|}
\hline \multirow[t]{2}{*}{ Location } & \multirow{2}{*}{$\begin{array}{l}\text { No. of } \\
\text { samples } \\
\text { placed }\end{array}$} & \multirow[t]{2}{*}{$\begin{array}{l}\text { Date and No. of } \\
\text { pupae placed }\end{array}$} & \multirow[t]{2}{*}{$\begin{array}{l}\text { Date and No. of } \\
\text { adults emerged }\end{array}$} & \multicolumn{2}{|c|}{$\begin{array}{c}\text { Number and percent of } \\
\text { Earias vitella }\end{array}$} \\
\hline & & & & Male & Female \\
\hline $\begin{array}{l}\text { Kaharole, } \\
\text { Dinajpur }\end{array}$ & 100 & $\begin{array}{c}\text { July } 252009 \\
73\end{array}$ & $\begin{array}{c}\text { August } 42010 \\
50\end{array}$ & $23(31.51)$ & 27 (36.99) \\
\hline $\begin{array}{l}\text { Panchbibi, } \\
\text { Joypurhat }\end{array}$ & 100 & $\begin{array}{c}\text { July } 262009 \\
68\end{array}$ & $\begin{array}{c}\text { August } 52010 \\
44\end{array}$ & $18(26.47)$ & $26(38.24)$ \\
\hline $\begin{array}{l}\text { Gazipur Sadar, } \\
\text { Gazipur }\end{array}$ & 100 & $\begin{array}{c}\text { August } 92009 \\
66\end{array}$ & $\begin{array}{c}\text { August } 182010 \\
42\end{array}$ & 19 (28.79) & $23(34.85)$ \\
\hline Kurigram Sadar & 100 & $\begin{array}{c}\text { July } 302009 \\
63\end{array}$ & $\begin{array}{c}\text { August } 82010 \\
40\end{array}$ & $18(28.57)$ & $22(34.92)$ \\
\hline $\begin{array}{l}\text { Mireresorai, } \\
\text { Chittagong }\end{array}$ & 100 & $\begin{array}{c}\text { August } 222010 \\
60\end{array}$ & $\begin{array}{c}\text { August } 302010 \\
38\end{array}$ & $18(30)$ & $20(33.33)$ \\
\hline $\begin{array}{l}\text { Ashashuni, } \\
\text { Shatkhira }\end{array}$ & 100 & $\begin{array}{c}\text { August } 282010 \\
70\end{array}$ & $\begin{array}{c}\text { September } 52010 \\
42\end{array}$ & $20(28.57)$ & $22(31.43)$ \\
\hline Porshuram, Feni & 100 & $\begin{array}{c}\text { August } 302010 \\
67\end{array}$ & $\begin{array}{c}\text { September } 62010 \\
38\end{array}$ & $16(23.88)$ & $22(32.84)$ \\
\hline Ishardi, Pabna & 100 & $\begin{array}{c}\text { September } 012010 \\
58\end{array}$ & $\begin{array}{c}\text { September } 212010 \\
32\end{array}$ & $15(25.86)$ & $17(29.31)$ \\
\hline $\begin{array}{l}\text { Gaugnee, } \\
\text { Meherpur }\end{array}$ & 100 & $\begin{array}{c}\text { September } 132010 \\
62\end{array}$ & $\begin{array}{c}\text { September } 252010 \\
40\end{array}$ & $16(25.81)$ & $24(38.71)$ \\
\hline $\begin{array}{l}\text { Kushtia Sadar, } \\
\text { Kushtia }\end{array}$ & 100 & $\begin{array}{c}\text { October } 102010 \\
59\end{array}$ & $\begin{array}{c}\text { October } 212010 \\
30\end{array}$ & $12(20.34)$ & $18(30.51)$ \\
\hline $\begin{array}{l}\text { Jhikargacha, } \\
\text { Jessore }\end{array}$ & 100 & $\begin{array}{c}\text { October } 222010 \\
56\end{array}$ & $\begin{array}{c}\text { November } 052010 \\
27\end{array}$ & $13(23.21)$ & $14(25)$ \\
\hline Total & 1100 & 702 & 423 & 188 & 235 \\
\hline
\end{tabular}

Male: Female $=1.00: 1.25$

\section{Distribution of Earias vittella on host and locality}

This study showed that 423 individuals emerged from 702 pupae (emergence rate $60.26 \%$ ) reared in infested okra collected from okra growing areas. The E. vittella predominantly emerged from the specimens collected from Dinajpur but were gradually decreased in the infested okra collected from other growing areas (Fig. 3). 


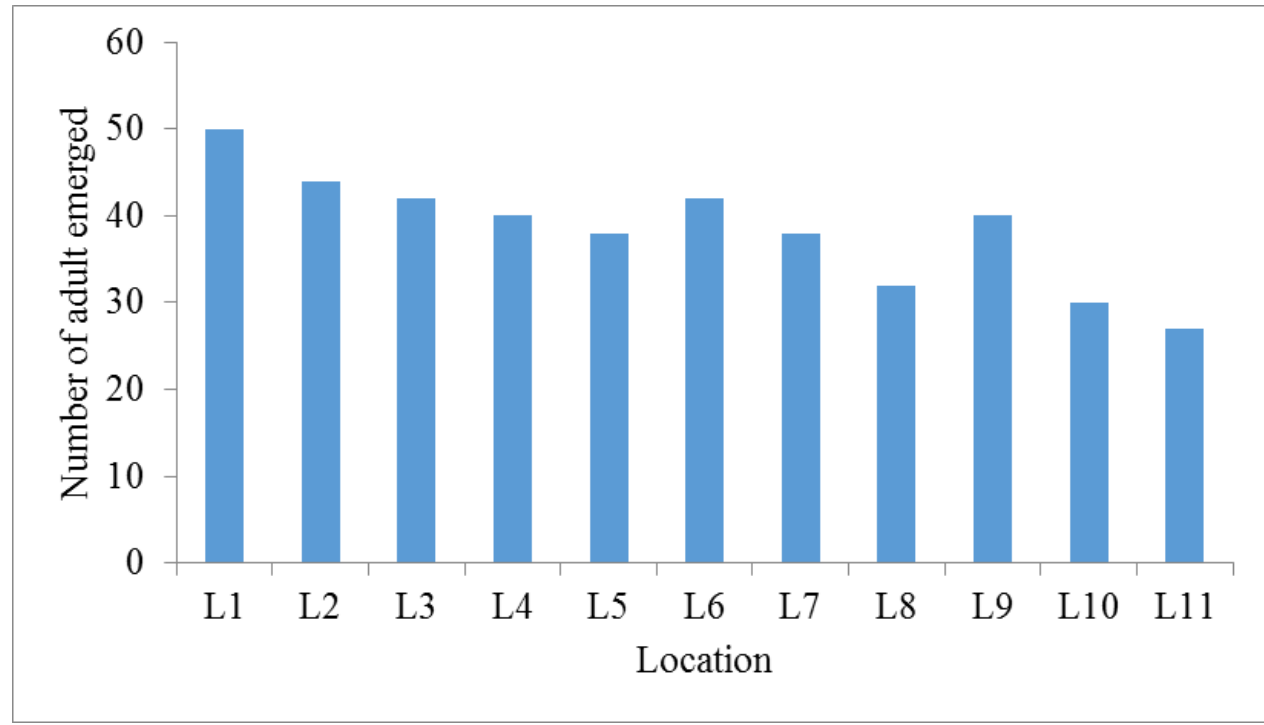

$\mathrm{L}_{1}=$ Dinajpur, $\mathrm{L}_{2}=$ Jaypurhat, $\mathrm{L}_{3}=$ Gazipur, $\mathrm{L}_{4}=$ Kurigram, $\mathrm{L}_{5}=$ Chittagong, $\mathrm{L}_{6}=$ Shatkhira, $\mathrm{L}_{7}=$ Feni, $\mathrm{L}_{8}=$ Pabna, $\mathrm{L}_{9}=$ Meherpur, $\mathrm{L}_{10}=$ Kushtia, $\mathrm{L}_{11}=$ Jessore

Fig. 3. Distribution of Earias vittella throughout 11 locations of Bangladesh.

The present study indicated that $E$. vittella is the only species under the genus Earias that bored into the okra fruit, though previous workers found other species in addition to E. vittella. Other borers (E. cupreoviridis and E. insulana) which attack okra are the borer of cotton ball and they choose okra fruit as alternate host. It is now necessary to undertake some more study to find out other borers which may attack okra as alternate host along with the molecular identification of that pest. An investigation may also be conducted to identify some of the invading Bangladeshi Malvaceaous crops.

\section{Reference}

Alam, M.Z. 1962. A List of Insects and Mites of East Pakistan. East Pakistan Agri. Res. Inst., Tejgaon, Dacca: 44-48

Alam, M.Z. 1969. Pests of cucurbit vegetables. In: insect-pests of vegetables and Their control in East Pakistan. Agri. Infor. Serv., Dept. Agri., Dacca: 87-110.

Ali, M.I. 1992. Seasonal occurrence of different cotton bolloworms on cotton in Bangladesh. Bangladesh J. Ent. 2 (1 \& 2):1-7.

Ali, M.I. and M.A. Karim. 1990. Host preference of spotted bollworm (Sbw), Earias vittella (F.) its potential use in Integrated Pest Management of the Sbw in cotton. Univ. J. Zool. Rajshahi. Univ. 9:81-83.

Ambekar, J.S., A.S. Pawar and M.V. Sakhare. 2000. Bio-efficacy of neem certain products against okra fruit borer. J. Maharashtra Agril. Univ. Pune, India. 25(1): 42-43. 
Anonymous. 2001. http://agritechthau.ac.in

Atwal, A.S. 1976. Agricultural Pest of India and South- East Asia. Kalyani Publishers. New Delhi, Ludhiana: Pp. 283-285.

Atwal and Dhaliwal, 1997. In: Agricultural Pests of South Asia and Their Management. Kalyani Publishers. New Delhi, Ludhiana: pp. 240-245.

Butani, D.K. and M.G. Jotwani. 1984. Insects in vegetables. Periodical Expert Book Agency. Vivek-Vihar, Delhi (India). Pp. 45-66.

Gapud, V.P. 1993. Insect and mite pests of plant erops in Bangladesh and their natural enemies. A consultancy report financed by USAID, Organised by BARC, Dhaka, Bangladesh. Pp. 34-38

Gautam, R.K. and Goswami, N. 2004. Different food varies for amino acids in moth larvae, Uttar Pradesh Zool. 24(2): 183-196.

Krishnaiah, K. 1980. Methodology for assessing crop losses due to pests of vegetables "Assessment of crop losses due to pest and diseases". Ed. Govindu. H.C. et al. USA Tech. Series No. 33: 259-267.

Satpute, N.S., S.D. Deshmukh, P.N. Mane, N.G.V. Rao, and S.A. Nimbalkar. 2002. Growth and development of spotted bollworm, Earias vittella (F) reared on different hosts under laboratory conditions. PKV Res. 26(1/2): 47-50.

Srinivasan, P.M. and R.B. Gowder. 1959. A preliminary note on the control of the bhendi shoot and fruit borer, Earias vittella $\mathrm{F}$ and E. insulana. Indian J. Agric. Sci. 30(1): 55-57. 